\title{
KOMUNIKASI DALAM PEMBERDAYAAN KELOMPOK DIFABEL (STUDI PADA UMKM BATIK WISTARA INDONESIA)
}

\author{
Siti Khalimatus Sya'diyah \\ Universitas Islam Negeri Sunan Ampel Surabaya \\ Sikhalisya25@gmail.com
}

\begin{tabular}{l}
\hline \hline Article Info \\
\hline Article history: \\
Received 10 Februari 2020 \\
Accepted 11 Maret 2020 \\
Published 10 April 2020 \\
\hline
\end{tabular}

Keyword:

Komunikasi

Pemberdayaan, Kelompok

Difabel

\section{Abstract}

This article discusses how to communicate in empowering groups with disabilities at UMKM Batik Wistara Indonesia. The purpose of this study is to describe the communication process carried out by UMKM Batik Wistara Indonesia to these disabled employees. This research uses a qualitative approach with descriptive methods.

The results of this study indicate that the communication process carried out by employees with disabilities uses the Schramm model and the interactional communication model, by applying a circular communication pattern. The form of the communication process carried out is interpersonal communication by referring to no limitations in communicating. Owners and managers of UMKM Batik Wistara Indonesia, when communicating with disabled employees at UMKM use egalitarian ways, so that employees can work comfortably without pressure from the manager.

Artikel ini membahas tentang cara komunikasi dalam pemberdayaan kelompok difabel pada UMKM Batik Wistara Indonesia Tujuan penelitian ini adalah mendeskripsikan proses komunikasi yang dilakukan oleh UMKM Batik Wistara Indonesia pada karyawan difabel tersebut. Penelitian ini menggunakan pendekatan kualitatif dengan metode deskriptif.

Hasil penelitian ini menunjukkan, bahwa proses komunikasi yang dilakukan oleh karyawan difabel menggunakan model Schramm dan model komunikasi interaksional, dengan menerapkan pola komuniksi lingkaran. Bentuk proses komunikasi yang dilakukan adalah komunikasi interpersonal dengan merujuk pada tidak ada batasan dalam berkomunikasi. Pemilik dan pengelola di UMKM Batik Wistara Indonesia, ketika berkomunikasi dengan karyawan difabel di UMKM tersebut menggunakan cara egaliter, sehinnga karyawan dapat bekerja dengan nyaman tanpa adanya tekanan dari pengelola.

Copyright (C) 2020 Jurnal Ilmu Komunikasi

\section{Editorial Office:}

Program Studi Ilmu Komunikasi, Fakultas Dakwah dan Komunikasi, UIN Sunan Ampel Surabaya. Jl. Ahmad Yani 117 Surabaya, Jawa Timur, Indonesia.

Email: jurnalilkom@uinsby.ac.id 


\section{Pendahuluan}

Manusia sebagai makhluk sosial, dalam kodratnya selalu membutuhkan orang lain untuk memenuhi kebutuhan, ingin mengetahui segala informasi disekitar, dan bahkan ingin mengetahui apa yang terjadi dalam dirinya. Rasa ingin tahu inilah yang mendorong manusia melakukan komunikasi.

Menurut Deddy Mulyana tentang definisi komunikasi, tidak ada definisi yang benar ataupun yang salah. Seperti juga model atau teori, definisi harus dilihat dari kemanfaatannya untuk menjelaskan fenomena yang didefinisikan dan mengevaluasinya. Beberapa definisi mungkin terlalu sempit, misalnya "Komunikasi adalah penyampaian pesan melalui media elektronik" atau terlalu luas, misalnya "Komunikasi adalah interaksi antara dua makhluk hidup atau lebih"'.

Menurut Everett Kleinjan dari East West Center Hawaii, komunikasi sudah merupakan bagian kekal dari kehidupan manusia seperti halnya bernafas. Selama manusia ingin hidup, ia perlu berkomunikasi. ${ }^{2}$ Sehingga dapat peneliti simpulkan bahwa dalam kehidupan bermasyarakat, jika seseorang cenderung menutup dirtanpa berkomunikasi ataupun bersosialisai dengan orang lain, maka orang tersebut akan terisolasi dari masyaratkatnya. Oleh sebab itu, proses

${ }^{1}$ Deddy Mulyana, Ilmu Komunikasi: Suatu Pengantar, cet. 9, (Bandung: PT Remaja Rosdakarya, 2007), 46.

${ }^{2}$ Hafied Cangara, Pengantar Ilmu Komunikasi Ed. 2, cet. 13, (Jakarta: Rajawali Pers, 2012), 1. komunikasi yang dilakukan tidak akan pernah berhenti

Pesan merupakan hal yang erat kaitannya dengan komunikasi. Sebuah pesan yang disampaikan oleh manusia dalam proses komunikasi tidak hanya berupa bahasa verbal, karena manusia dengan berbagai kemampuan berpikirnya akan menciptakan sebuah lambang atau simbol untuk menyampaikan sesuatu sesuai keinginannya.

Komunikasi selalu terjadi dalam keadaan spesifik. Ketika berinteraksi dengan orang lain, akan ada sejumlah informasi yang diberikan kepada orang tersebut. begitu pula sebaliknya. Seseorang tidak hanya memperhatikan apa yang lawan bicara kita bicarakan, namun juga informasi non-verbal yang diberikan. Misalnya, sikap atau gerak geriknya selama bicara, ekspresi wajah, orientasi tubuh, nada bicara, jarak antara keduanya, kontak mata dan lain sebagainya. kesemua hal tersebut tergolong dalam komunikasi non verbal, yaitu sebuah bentuk komunikasi yang dapat melengkapi informasi yang diberikan oleh lawan bicara. ${ }^{3}$ Hal ini juga berlaku bagi sebagian orang yang memiliki keterbatasannya dalam hal berkomunikasi.

Rudiantara mengatakan ada 20 juta orang difabel seperti tuna grahita, tuna daksa, tuna rungu, dan lain sebagainya. Melalui kebijakan bahasa isyarat ini, berharap para penyandang difabel juga

3 Sarlito W. Sarwono, Psikologi Lintas Budaya Ed. 1 cet. 1, (Jakarta: Rajawali Pers, 2014), 64. 
dapat merasakan apa yang dirasakan oleh orang-orang lain di Indonesia ${ }^{4}$.

Terlepas dari kesulitan dalam memperoleh informasi, penyandang difabel kerap dipandang sebelah mata oleh orang - orang pada umumnya. Data Kementerian Sosial pada tahun 2010 menyebutkan bahwa jumlah penyandang difabel mencapai 11.580 .117 orang namun mayoritas dari mereka tidak bekerja karena peluang kerja bagi para penyandang difabel sangat terbatas, terutama untuk pekerjaan di sektor formal. ${ }^{5}$

Penyandang difabel merupakan bagian dari warga negara Indonesia yang juga memiliki kedudukan, hak dan kewajiban yang sama dengan masyarakat Indonesia pada umumnya. Kesamaan hak tersebut terdapat pada filsafat Negara Pancasila dan Undang-Undang 1945. Dalam UUD 1945 pasal 27 ayat 2 "Tiap warga negara berhak atas pekerjaan dan penghidupan yang layak bagi kemanusiaan". Selain itu, Peraturan Pemerintah juga mengatur penyandang difabel dalam bekerja, seperti dalam Undang-Undang No. 8 Tahun 2016 Tentang Penyandang Difabel Pasal 53 yang mewajibkan semua instansi pemerintah, pemerintah daerah, badan usaha milik negara ataupun badan usaha milik daerah menerima $2 \%$ penyandang difabel dari total jumlah pegawai atau

4 Tempo.co, "Penggunaan Bahasa Isyarat di Acara Televisi Akan Diwajibkan" September 25, 2019, http//www.tempo.co.

5 Antaranews.com., Penyandang disabilitas Spanyol protes penghematan anggaran, September, 25, 2019,

http://www.antaranews.com/print/346542/penyand ang-disabilitas-spanyol-protespenghematananggaran

6 Andi Maulana Armas, Andi Alimuddin Unde, dan Jeanny Maria Fatimah, Konsep Diri Dan pekerja yang ada di instansi tersebut dan $1 \%$ dari total jumlah pegawai di isntansi swasta. Namun pada kenyataanyannya kuota $2 \%$ untuk instansi pemerintah dan $1 \%$ untuk instansi swasta tidak terpenuhi dan tidak berjalan efektif. ${ }^{6}$

Menurut data dari ILO (International Labour Organization) atau Organisasi Buruh Internasional (2013), pada negara berkembang termasuk Indonesia terdapat jutaan penyandang difabel baik perempuan dan laki-laki berada pada usia kerja, namun mayoritas tidak bekerja. Hal tersebut menunjukkan bahwa masih banyak masyarakat penyandang difabel kesulitan untuk memperoleh pekerjaaan baik itu pada instansi swasta maupun pemerintahan. Selain sulit mendapatkan pekerjaan, penyandang difabel yang akhirnya mendapatkan pekerjaan tidak jarang mendapatkan diskriminasi di tempat kerja $^{7}$.

Surabaya merupakan salah satu kota besar yang memiliki pertumbuhan ekonomi yang cukup pesat. Persaingan dalam memperoleh pekerjaan dan mendirikan sebuah usaha juga sangat signifikan, akan tetapi peneliti tertarik pada sebuah usaha pembuatan dan pengolahan batik yang ada di Surabaya bernama Batik Wistara Indonesia. Pada dasarnya usaha ini sama seperti pada usaha yang lain, namun

Kompetensi Komunikasi Penyandang Disabilitas Dalam Menumbuhkan Kepercayaan Diri Dan Aktualisasi Diri Di Dunia Kewirausahaan Kota Makassar, Jurnal Komunikasi KAREBA 6 no. 2 (Desember 2017): 279. https://doi.org/10.31947/kjik.v6i2.5328

7 International Labour Organization Jakarta. Inklusi penyandang disabilitas di Indonesia. Maret 7, 2016, http://www.ilo.org/jakarta/whatwedo/publications /WCMS_233426/lang--en/index.htm 
yang membedakan yakni karyawan yang dipekerjakan adalah kelompok difabel.

UMKM Batik Wistara Indonesia memberikan keterampilan pada kelompok difabel yang tidak bisa ataupun yang sudah bisa dengan cara diberdayakan untuk meningkatkan keterampilan mereka. Dalam hal ini, keterampilan yang diberikan berupa cara menjahit pakaian dan juga membuat batik.

Proses pemberian keterampilan dengan cara diberdayakan inilah, yang membuat peneliti tertarik dan berasumsi bahwa kelompok difabel yang diberdayakan di Batik Wistara Indonesia memiliki komuniksi serta faktor pendukung dan penghambat dalam proses komunikasinya. Sehingga peneliti mengambil judul skripsi yakni komunikasi dalam pemberdayaan kelompok difabel yang peneliti khususkan pada studi penelitian di UMKM Wistara Indonesia.

\section{Kajian Pustaka}

\section{Komunikasi}

Menurut Kamus Besar Bahasa Indonesia (KBBI) komunikasi adalah suatu proses penyimpana informasi (pesan, ide, gagasan) dari satu pihak ke pihak yang lain $^{8}$. Menurut Wiranto dalam bukunya, berpendapat bahwa ilmu komunikasi berasal dari berbagai disiplin ilmu. Oleh karena itu, hal ini membuat para ahli mendefinisikannya dalam sudut pandang mereka masing-masing ${ }^{9}$.

8 Ngalimun, Ilmu Komunikasi Sebuah Pengantar Praktis, (Yogyakarta: Pustaka Baru Press, 2017), 19.

9 Wiryanto, Pengantar Ilmu Komunikasi, (Jakarta: PT Grasindo, 2004), 5.
Hoveland mendefinisikan komunikasi, demikian: "The Process by which an individual (the communicator) transmits stimuli (usualy verbal symbols) to modify, the behaviour of other individu". (Komunikasi adalah proses dimana individu mentransmisikan stimulus untuk mengubah perilaku individu yang lain. ${ }^{10}$ )

Onong Uchjana Effendy dalam bukunya berpendapat bahwa Definisi Hoveland menunjukkan bahwa yang dijadikan objek studi ilmu komunikasi bukan saja penyampaian informasi, melainkan juga pembentukan pendapat umum (public opinion) dan sikap publik (public attitude) yang dalam kehidupan sosial dan kehidupan politik memainkan peranan yang sangat penting. Bahkan dalam definisinya secara khusus mengenai pengertian komunikaisnya sendiri ${ }^{11}$.

Komunikasi merupakan implementasi dari berbagai multi displin ilmu, dimana komunikasi akan memliki perbedaan disetiap situasi, kondisi, bahkan dari suasana hati dapat memiliki arti yang berbeda. Namun terlepas dari semuanya, menurut peneliti sejatinya manusia bahkan tanpa dikehendakipun proses komunikasi yang dilakukan tidak akan berhenti ${ }^{12}$.

Menurut peneliti berdasarkan pengertian di atas, komunikasi berarti cara bagaimana seseorang mengungkapkan apa yang dipikirkan berupa pesan kemudian disampaikan kepada orang lain, baik berupa pesan verbal maupun nonverbal.

${ }^{10}$ Carl I Hoveland, Social Communication, Am Phil. Soc, XCII, (Dance No. 33/Catg. Stappers 1948), 371

${ }^{11}$ Onong Uchjana Effendy, Ilmu Komunikasi Teori dan Praktek, (Bandung: PT Remaja Rosdakarya, 2009), 10.

${ }^{12}$ Mulyana, Ilmu Komunikasi, 92. 
Komunikasi UMKM Batik Wistara Indonesia dalam memberdayakan kelompok difabel masalah terbesar adalah proses cara berkomunikasi. Banyak faktor - faktor yang mempengaruhi serta ketidakmampuan berkomunikasi jelas memberikan dampak yang luas. Sedangkan pemberdayaan yang dimaksud adalah proses pemberian pelatihan keterampilan untuk meningkatkan potensi kerja ynag dimiliki oleh kelompok defabel tersebut.

\section{Pemberdayaan}

Secara konseptual, pemberdayaan atau pemberkuasaan (empowerment), berasal dari kata 'power' (kekuasaan atau keberdayaan). Karenanya, ide utama pemberdayaan bersentuhan dengan kemampuan kita untuk membuat orang lain melakukan apa yang kita inginkan, terlepas dari keinginan dan minat mereka. Ilmu sosial tradisional menekankan bahwa kekuasaan berkaitan dengan pengaruh dan kontrol $^{13}$.

Pemberdayaan menunjuk pada kemampuan orang, khususnya kelompok rentan dan lemah sehingga mereka memiliki kekuatan atau kemampuan dalam (a) memenuhi kebutuhan dasarnya sehingga mereka memiliki kebebasan (freedom), dalam arti bukan saja bebas mengemukakan pendata, melainkan bebas dari kelaparan, bebas dari kebodohan, bebas dari kesakitan; (b) menjangkau sumber-sumber produktif yang memungkinkan mereka dapat

13 Edi Suharto, Membangun Masyarakat Memberdayakan Rakyat Kajian Strategis Pembangunan Kesejahteraan Sosial dan Pekerjaan Sosial, (Bandung: PT Revika Aditama, 2010), 57. meningkatkan pendapatnya dan memperoleh barang dan jasa yang merekaperlukan; dan (c) berpartisipasi dalam proses pembangunan dan keputusan yang mempengaruhi mereka ${ }^{14}$.

Tujuan utama pemberdayaan adalah memperkuat kekuasaan masyarakat, khususnya kelompok lemah yang memiliki ketidakberdayaan, baik karena kondisi internal (misalnya ditindas oleh struktur sosial yang tidak adil). Guna melengkapi pemahaman mengenai pemberdayaan perlu diketahui konsep mengenai kelompok lemah dan ketidakberdayaan yang dialaminya ${ }^{15}$.

Kelompok-kelompok tertentu yang mengalami diskriminasi dalam suatu masyarakat, seperti masyarakat kelas sosial ekonomi rendah, kelompok minoritas etnis, wanita, populasi lanjut usia, serta para penyandang cacat, adalah orang-orang yang mengalami ketidakberdayaan. Keadaan dan perilaku mereka yang berbeda dari 'kerumunan' kerap kali dipandang sebagai 'deviant' (penyimpang). Mereka seringkali kurang dihargai dan bahkan dicap sebagai orang malas, lemah, yang disebabkan oleeh dirinya sendiri. Padahal ketidakberdayaan mereka seringkali merupakan akibat dari adanya kekurangadilan dan diskriminasi dalam aspek-aspek kehidupan tertentu.

Menurut peneliti berdasarkan pengertian di atas, pemberdayaan adalah upaya yang dilakukan seseorang atau kelompok organisasi dalam meningkatkan

14 Edi Suharto, Pembangunan, Kebijakan Sosial dan Pekerjaan Sosial: Spektrum pemikiran, (Bandung: Lembaga Studi Pembangunan STKS (LSP-STKS), 1997), 210-224.

${ }^{15}$ Suharto, Membangun Masyarakat, 60. 
kualitas hidup seseorang, baik kebutuhan ekonomi maupun kemampuan kerja seseorang. Sedangkan dalam konteks penelitian yang peneliti angkat mengenai pemberdayaan kelompok difabel yakni sebuah proses pemberian keterampilan berupa menjahit dan membatik untuk meningkatkan potensi kerja yang dimiliki oleh kelompok difabel yang dalam hal ini merupakan karyawan yang dimiliki oleh UMKM Wistara Indonesia. Sedangkan komunikasi merupakan proses antara pemilik, pengelola, pendamping serta seluruh karyawan difabel menyampaikan.

\section{Kelompok Difabel}

Undang-Undang Republik Indonesia Nomor 4 Tahun $1997^{16}$ tentang Penyandang Cacat (difabel) bertujuan untuk menciptakan/agar:

1. Upaya peningkatan kesejahteraan sosial penyandang cacat berlandaskan Pancasila dan Undang-Undang Dasar 1945.

2. Setiap penyandang cacat mempunyai kesamaan kesempatan dalam segala aspek kehidupan dan penghidupan.

Adapun jenis dan penyebab kecacatan bisa disebabkan oleh berbagai faktor yaitu: 1. Cacat didapat (Acquired), penyebabnya bisa karena kecelakaan lalu lintas, perang/konflik bersenjata atau akibat penyakit-penyakit kronis.

2. Cacat bawaan/sejak lahir (Congenital), penyebabnya antara lain karena kelainan pembentukan organ-organ

${ }^{16}$ BPKP - Unduhan UU RI No.4 Tahun 1997, September, 26, 2019, www.bpkp.go.id > uu > (organogenesis) pada masa kehamilan, karena serangan virus, gizi buruk, pemakaian obat-obatan tak terkontrol atau Karen apenyakit menular seksual $^{17}$

Menurut UU Penyandang Cacat, berbagai faktor penyebab serta permasalahan kecacatan, maka jenis-jenis kecacatan dapat di kelompokkan sebagai berikut :

1. Tuna Netra adalah seseorang yang terhambat mobilitas gerak yang disebabkan oleh hilang/berkurangnya fungsi penglihatan sebagai akibat dari kelahiran, kecelakaan maupun penyakit yang terdiri dari:

a. Buta total, tidak dapat melihat sama sekali objek di depannya (hilangnya fungsi penglihatan).

b. Persepsi cahaya, seseorang yang mampu membedakan adanya cahaya atau tidak, tetapi tidakdapat menentukan objek atau benda di depannya.

c. Memiliki sisa penglihatan (low vision), seseorang yang dapat melihat benda yang ada di depannya dan tidak dapat melihat jari-jari tangan yang digerakkan dalam jarak satu meter.

2. Tuna Rungu/ Wicara adalah kecacatan sebagai akibat hilangnya/ terganggunya fungsi pendengaran dan atau fungsi bicara baik disebabkan oleh kelahiran, kecelakaan maupun

${ }^{17}$ Sapto Nugroho, Risnawati Utami, Meretas Siklus Kecacatan-Realitas Yang Terabaikan, (Surakarta: Yayasan Talenta, 2008), 114. 
penyakit, terdiri dari tuna rungu wicara, tuna rungu, tuna wicara.

3. Tuna Daksa adalah cacat pada bagian anggota gerak tubuh. suatu keadaan rusak atau terganggu, sebagai akibat gangguan bentuk atau hambatan pada tulang, otot, dan sendi dalam fungsinya yang normal. Kondisi ini dapat disebabkan oleh penyakit, kecelakaan atau dapat juga disebabkan oleh pembawaan sifat lahir ${ }^{18}$.

Menurut peneliti dari kesimpulan di atas bahwa, kelompok difabel merupakan kelompok yang memiliki keterbatasan dalam kehidupannya, baik dalam hal berbicara, mendengarkan, bergerak dan lain sebagainya. Keterbatasan inilah kerap membuat mereka dipandang sebelah mata oleh masyarakat awam.

\section{Usaha Mikro Kecil Menengah (UMKM)}

Usaha Menengah adalah usaha ekonomi produktif yang berdiri sendiri, yang dilakukan oleh orang perorangan atau badan usaha yang bukan merupakan anak perusahaan atau cabang perusahaan yang dimiliki, dikuasai, atau menjadi bagian baik langsung maupun tidak langsung dengan Usaha Kecil atau Usaha Besar dengan jumlah kekayaan bersih atau hasil penjualan tahunan ${ }^{19}$.

\section{Metode Penelitian}

\footnotetext{
18 T. Sutjihati Soemantri, Psikologi Anak Luar Biasa, (Bandung : Refika Aditama, 2006), 121.

19 Mudrajat Kuncoro, Masalah, Kebijakan, dan Politik Ekonomika Pembangunan, (Jakarta, 2010), 54.
}

Penelitian ini menggunakan metode penelitian kualitatif deskriftif. Menurut Kriyantono pendekatan kualitatif adalah penelitian yang bertujuan untuk menjelaskan fenomena dengan sedalamdalamnya melalui pengumpulan data sedalam-dalamnya dengan lebih ditekankan pada persoalan kedalaman (kualitas) data bukan banyaknya (kuantitas) data" ${ }^{20}$.

Dalam hal ini tujuan menggunakan pendekatan kualitatif ini adalaha untuk memperoleh informasi secara mendetail mengenai proses komunikasi yang dilakukan UMKM Batik Wistara Indonesia dengan kelompok difabel saat berkomunikasi, serta hambatan yang dilaluinya. Sehingga peneliti mampu memahami dan menjelaskan bagaimana komunikasi yang terjadi diantara keduanya.

Dalam penelitian ini peneliti memfokuskan pada teknik analisis data model alir Miles dan Huberman dimana tahap ini menekankan pada tiga alur yaitu; reduksi data, penyajian data, dan penarikan kesimpulan atau verifikasi ${ }^{21}$.

\section{Hasil Dan Pembahasan}

Batik Wistara Indonesia merupakan Usaha Mikro Kecil Menengah (UMKM) bergerak di bidang pembuatan dan pengolahan batik yang bertempat di $\mathrm{Jl}$. Tambak Medokan Ayu VI C No.56B, Medokan Ayu, Kec. Rungkut, Kota

20 Lexy J. Moloeng, Metode penelitian kualitatif, (Bandung: Remaja Rosdakarya, 2006 ), 68 .

${ }^{21}$ A. Michael Matthew Hubberman dan Miles B., Analisis Data Kualitatif. Terj. Tjejep, (Jakarta :UI Press, 1992), 20. 
Surabaya. UMKM Batik Wistara Indonesia berdiri pada tahun 2010, bermula dari usaha kecil hingga akhirnya menjadi dikenal dikalangan pecinta batik. Batik Wistara Indonesia memiliki ciri khas "Mix of Culture, Ethnic, and Art. Give a different touch of heritage. Indonesian to enrich the creative art of exceptional Masterpieces. Style is an art that became the soul" yang berarti Perpaduan antara Budaya, Etnik, dan Seni. Memberikan sentuhan yang berbeda dari warisan leluhur memperkaya cipta seni Indonesia menjadi Mahakarya yang luar biasa, Gaya adalah seni yang menjadi jiwa (wistara.us, dakses 25 September 2019).

Batik Wistara Indonesia memiliki 16 orang karyawan, yang keseluruhannya penyandang difabel. Mereka semua adalah anak-anak penyandang tuna rungu dan tuna wicara. Serta memiliki satu orang pendamping normal. Seluruh karyawan berasal dari daerah yang berbeda ${ }^{22}$. Seluruh karyawan di Batik Wistara Indonesia memiliki keuntungan yakni mendapatkan tempat tinggal, makan dan bekerja ditempat yang sama.

Visi dari UMKM Batik Wistara Indonesia yakni sebagai wadah untuk penyandang difabel. Serta memiliki Misi mampu mengembangkan batik sebagai warisan leluhur untuk bisa lebih dikenal ${ }^{23}$. Struktur UMKM Batik Wistara Indonesia, Pak Ariyono Setiawan sebagai Owner atau pemilik langsung membawahi Ibu Sumarni sebagai pengelola, selanjutnya Harum Kusuma Ningsih menjadi pendamping

22 Marni, Wawancara, (selaku Pengelola UMKM Batik Wistara Indonesia) November, 24, 2019. dalam berhubungan dengan karyawan lain serta membantu pekerjaan dari bu Sumarni.
1. Proses
Komunikasi
Dalam

Pemberdayaan Kelompok Difabel di UMKM Batik Wistara Indonesia

a. Proses komunikasi antara karyawan difabel dengan pemilik

Proses komunikasi yang terjadi antara pemilik dan karyawan difabel dalam pemberdayaan yang dilakukan, tergambar melalui salah satu pengamatan peneliti dari sebuah kejadian.

Proses komunikasi yang terjadi antara keduanya tidak memiliki batasan, seperti Pak ari selaku pemilik hanya menggunakan bahasa isyarat sebisa yang ia pahami begitu juga sebaliknya. Komunikasi yang dilakukan berjalan terus menerus hingga pesan dapat diterima dengan baik.

\section{b. Proses komunikasi antara karyawan difabel dengan pengelola}

$\mathrm{Bu}$ Marni merupakan seseorang yang mengelola Batik Wistara Indonesia dan seseorang yang juga hidup bersama dengan karyawan difabel setiap harinya. Hal ini jelas jika Bu Marni mengetahui secara menyeluruh keseharian dan selalu berkomunikasi dengan karyawan

23 Ari, Wawancara, (selaku Pemilik UMKM Batik Wistara Indonesia), November 17, 2019. 
difabel yang ada di UMKM Batik

Wistara Indonesia

Proses komunikasi yang dilakukan karyawan difabel dengan pengelola juga tidak jauh berbeda dengan pemilik sebelumnya. Dalam wawancara dengan peneliti, mereka mengungkapkan tidak ada kendala dalam berkomunikasi.

Komunikasi yang dilakukan antara keduanya juga tidak terbatasa, hingga pesan yang disampaikan dapat dipahami dengan baik, mereka mnggunakan segala macam cara, tidak hanya menggunakan bahasa isyarat tetapi juga bahasa pendukung lainnya seperti bahasa tubuh dan isyarat bibir.

c. Proses komunikasi antara karyawan difabel dengan pendamping

Harum selaku pendamping di UMKM Batik Wistara Indonesia juga memberikan penjelasan bagaimana saat dia berkomunikasi dengan karyawan difabel.

Bahasa isyarat sesuai dengan pedoman Sistem Isyarat Bahasa Indonesia (SIBI) juga dilakukan untuk mempermudah berkomunikasi dengan karyawan difabel karena notabene mereka sudah memilki pengetahuan tersebut saat masih kecil.

\section{d. Proses komunikasi antara sesama karyawan difabel}

Selain komunikasi yang dilakukan antara pemilik, pengelola dan pendamping dengan karyawan difabel. Komunikasi antara karyawan sebagai komunikatornya juga perlu diperhatikan. peneliti juga bertanya bagaimana mereka berkomunikasi satu sama lain.

e. Proses komunikasi antara pemilik dengan pengelola

Proses komunikasi yang terjadi antara pemilik dan pengelola dalam pemberdayaan yang dilakukan tergambar dalam satu kejadian saat peneliti melakukan pengamatan di UMKM Wistara Indoensia sebagai berikut:

Pesan yang disampaikan jelas dapat diterima dengan baik dari pemilik kepada pengelola. Hal ini membuar proses komunikasi berjalan dengan lancar tanpa ada hambatan apapun.

\section{f. Proses komunikasi antara pemilik dengan pendamping}

Komunikasi yang dilakukan antara pemilik dan pendamping dalam pemberdayaan juga berjalan sesuai dengan semestinya karena mereka juga tidak memiliki keterbatasan dalam berkomunikasi. Hal ini tergambar dalam satu kejadian saat peneliti melakukan pengamatan di UMKM Wistara Indoensia sebagai berikut:

Penyampaina pesan dari pemilik kepada pendamping saat 
berkomunikasi dapat tersampaikan dengan baik, hal ini dikarenakan tidak ada batasan komunikasi seperti pada saat berkomunikasi dengan karyawan difabel.

\section{g. Proses komunikasi antara pengelola dengan pendamping}

Proses komunikasi yang terjadi antara pengelola dan pendamping dalam pemberdayaan yang dilakukan berjalan sesuai dengan semestinya karena pada dasarnya mereka tidak memiliki keterbatasan dalam berkomunikasi. Hal ini tergambar dalam satu kejadian saat peneliti melakukan pengamatan di UMKM Wistara Indoensia.

Penyampaina pesan dari pengelola kepada pendamping saat berkomunikasi dapat tersampaikan dengan baik, hal ini dikarenakan tidak ada batasan komunikasi seperti pada saat berkomunikasi dengan karyawan difabel.

\section{Faktor yang Menentukan dalam Pemberdayaan Kelompok Difabel di Batik Wistara Indonesia}

Saat melakukan pemberdayaan, dalam proses komunikasi yang dilakukan baik dari pemilik, pengelola maupun pendamping tentunya memiliki beberapa faktor yang mendukung. Selain itu, dari keseluruhan wawancara peneliti dengan karyawan difabel, mereka beranggapan antara satu dengan yang lain karena dirasa sudah sama-sama mengerti dengan bahasa isyarat yang digunakan dalam berkomunikasi. Adapun factor yang menentukan dalam pemberdayaan kelompok difabel di batik Wistara Indonesia adalah sebagai berikut:

\section{a. Komunikasi Menjadi Tidak} Terbatas

Hasil dari analisis data yang peneliti lakukan, maka proses komunikasi yang dilakukan karyawan difabel menggunakan model komunikas Schramm yakni komunikasi senantiasa membutuhkan setidaknya tiga unsur: sumber (source), pesan (message), dan sasaran (destination). Dalam model ini terdapat umpan balik atau feed back. Selain itu dalam proses komunikasi yang dilakukan juga mengandung model interaksional dimana komunikasi dilakukan dalam upaya interaksi sosial.

Pola komunikasi yang terjadi dapat diidentifikasi menggunakan pola komunikasi lingkaran yakni pola komunikasi yang lebih bersifat dinamis dalam penyebaran pesan, karena setiap orangnya terhubung dan dapat saling berkomunikasi dengan dua orang uang bersebelahan dengannya.

Peneliti mampu menyimpulkan jika proses komunikasi yang dilakukan merupakan implementasi dari bentuk komunikasi interpersonal dimana dalam prosesnya merujuk pada tidak ada batasan dalam berkomunikasi. Pemilik dan 
pengelola di UMKM Batik Wistara

Indonesia, ketika mereka

berkomunikasi dengan karyawan

difabel di UMKM Batik Wistara

Indonesia ini walaupun harus berusaha lebih keras daripada dengan yang lain. Baik dalam memahami apa yang disampaikan hingga sedikit banyak harus memiliki pengetahuan tentang bahasaisyarat yang digunakan. Oleh karena itu dapat peneliti uraikan secara urut yakni: karyawan difabel mengirim pesan (berupa simbol baik dengan bahasa isyarat, gerak bibir maupun gerak tubuh), selanjutnya pemilik dan pengelola menerima pesan sebisa mereka pahami, pemilik dan pengelola mengirim pesan kembali (berupa simbol baik dengan bahasa isyarat, gerak bibir maupun gerak tubuh), karyawan difabel menerimanya kembali dan memahami sebisanya, kemudian mengirim pesan lagi. Dan begitu seterusnya hingga kedua belah pihak akhirnya sepakat dan pesanan yang diterima sesuai.

Pesan dalam pemberdayaan yang dilakukan di UMKM Wistara Indonesia merupakan bagian darri proses komunikasi. Dari analisis peneliti, pesan-pesan tersebut melitputi; pemberian keterampilan, pengetahuan, dan motivasi.

Keterampilan (Skill) meliputi tindakan nyata dari perilaku, yang merupakan kemampuan seseorang dalam mengolah perilaku yang diperlukan dalam berkomunikasi secara tepat dan efektif. Di tempat Batik Wistara Indonesia melakukan beberapa pelatihan keterampilan seperti menjahit dan membuat batik. Pelatihan ini bertujuan untuk meningkatkan kemampuan yang sebelumnya karyawan difabel miliki. Tidak hanya itu, dari wawancara peneliti dengan salah satu karyawan difabel bernama Rossy Rosdiana mengaku jika di Batik Wistara Indonesia, mendapatkan pelatihan seperti cara melipat baju agar pas di masukkan ke tas plastik, serta menyetrika baju sesuai dengan lipatan jahitan agar rapi.

Harum selaku pendamping juga memberikan informasi yang seharusnya dilakuka jika karyawan difabel melakukan kesalahan dengan cara berkomunikasi menggunakan bahasa isyarat yang dipahami.

Motivasi

(motivation) biasanya berhubungan dengan tujuan-tujuan tertentu yang ingin dicapai, seperti untuk menjalin hubungan baru, mendapatkan informasi yang diinginkan, dan lain sebagainya. Semakin individu memiliki keinginan untuk berkomunikasi secara efektif dan meninggalkan kesan yang baik terhadap orang lain, maka akan semakin tinggi motivasi individu untuk berkomunikasi.

Pemberian motivasi yang dilakukan $\mathrm{Bu}$ Marni selaku 
pengelola Batik Wistara Indonesia berupa ajakan untuk rajin, tidak malas, jangan lupa menabung dan lain sebagainya yang bersifat pemberian semangat dalam bekerja. Dalam kehidupan seharisehari, Bu Marni juga memberikan pembentukan karakter kepada karyawan difabel seperti sopan santun, selalu hidup rukun dengan teman-teman, jangan suka bertengkar, dan displin dalam bekerja. Dari pembentukan karakter melalui motivasi ini akan berpengaruh pada bagaimana konsep diri dari karyawan difabel di UMKM Batik Wistara Indonesia.

Konsep tentang diri merupakan hal yang penting bagi kehidupan individu karena konsep diri menentukan bagaimana individu bertindak dalam berbagai situasi. Konsep diri juga merupakan sekumpulan keyakinan dan perasaan seseorang mengenai dirinya. Oleh karena itu adanya motivasi dari luar sangat diperlukan dalam rangka membangun konsep diri yang lebih baik.

Temuan peneliti mengenai komunikasi menjadi tidak terbatas merujuk pada cara bagaimana baik pemilik, pengelola, pendamping maupun karyawan difabel terus menerus dilakukan tanpa ada batasan. Berbagai cara dilakukan agar pesan yang ingin disampaikan baik penyampaian pelatihan keterampilan, pengetahuan dan motivasi dapat diterima dengan baik.

b. Bahasa Isyarat Sebagai Media Berkomunikasi

Bahasa adalah sistem lambang bunyi yang arbitrer yang dipergunakan oleh masyarakat untuk bekerja sama, Menurut peneliti, ada yang perlu digaris bawahi yakni bahasa digunakan dalam berkomunikasi. Sebagai sarana berkomunikasi, tentunya bahasa memiliki peranan penting. Proses komunikasi yang ada di UMKM Batik Wistara Indonesia tentunya tidak lepas dari penggunaan bahasa. Namun, sedikit memiliki perbedaan yakni bahasa yang digunakan tidak sama seperti orang-orang pada umumnya. Karena di tempat tersebut memiliki pekerja dengan penyandang disabillitas.

Bahasa isyarat yang digunakan oleh karyawan difabel di UMKM Batik Wistara yaitu menggunakan Bahasa Isyarat Indonesia (BISINDO) dan Sistem Isyarat Bahasa Indonesia (SIBI). Selain itu, mereka juga menggunakan gerak bibir dan bahasa tubuh, termasuk ekspresi wajah, pandangan mata, dan gerak tubuh sebagai penegas dalam menyampaikan sebuah pessan.

BISINDO merupakan bahasa isyarat yang muncul secara alami dalam budaya Indonesia dan praktis untuk digunakan dalam 
kehidupan sehari-hari sehingga BISINDO memiliki beberapa variasi di tiap daerah. Sementara itu, SIBI merupakan sistem isyarat yang yang diakui oleh pemerintah dan digunakan dalam pengajaran di Sekolah Luar Biasa untuk Tunarungu (SLB/B). Salah satu perbedaan BISINDO dan SIBI yang cukup terlihat adalah BISINDO menggerakkan dua tangan untuk mengisyaratkan abjad, sedangkan SIBI hanya menggunakan satu tangan saja. Bahasa isyarat ini muncul secara alami dan disesuaikan dengan budayanya masing-masing hingga saat ini belum ada bahasa isyarat terstandar internasional. Oleh karena itu, setiap negara memiliki bahasa isyaratnya masing-masing, termasuk Indonesia.

Pada dasarnya bahasa isyarat yang dilakukan $\mathrm{Bu}$ Marni tidak jauh berbeda dengan orang-orang pada umumnya. Seperti terlihat saat mereka melakukan komunikasi, Bu Marni menggunakan gerak tubuh seperti menyampaikan waktu atau jam yakni menunjuk tangan ke arah jam yang biasanya di tangan, menyampaikan waktu pasti pada pukul delapan dengan menunjukkan jari berjumlah depalan, serta mengucapkan kalimat larangan dengan melambaikan tangan larangan.

Selain itu saat Harum berkomunikasi dengan karyawan difabel tidak jauh berbeda. Namun, karena memiliki latar belakang mampu berkomunikasi dengan bahasa isyarat sesuai dengan Bahasa Isyarat Indonesia (BISINDO) atau Sistem Isyarat Bahasa Indonesia (SIBI) membuat Harum mampu berkomunikasi dengan karyawan difabel lainnya.

Selain bahasa isyarat yang mebedakan, proses komunikasi antara karyawan difabel dengan pemilik dan pengelola berjalan sesuai seperti komunikasi yang dilakukan oleh orang-orang umum lainnya. Oleh karena itu dapat peneliti uraikan secara urut yakni: karyawan difabel mengirim pesan (berupa simbol baik dengan bahasa isyarat, gerak bibir maupun gerak tubuh), selanjutnya pemilik dan pengelola menerima pesan sebisa mereka pahami, pemilik dan pengelola mengirim pesan kembali (berupa simbol baik dengan bahasa isyarat, gerak bibir maupun gerak tubuh), karyawan difabel menerimanya kembali dan memahami sebisanya, kemudian mengirim pesan lagi. Dan begitu seterusnya hingga kedua belah pihak akhirnya sepakat dan pesanan yang diterima sesuai.

Tidak hanya itu, komunikasi diantara sesama karyawan difabel selain bahasa isyarat juga memiliki kesamaan dalam proses komunikasinya. Dari hasil wawancara peneliti dengan karyawan difabel, dalam keseharian mereka berkomunikasi 
dengan bahasa isyarat sesuai dengan Bahasa Isyarat Indonesia (BISINDO) atau Sistem Isyarat Bahasa Indonesia (SIBI). Karena dengan keterbatasan yang mereka miliki, pengetahuan mengenai bahasa isyarat sudah mereka terima sejak kecil. Pesan-pesan non verbal lainnya juga dapat tersampaikan dengan baik.

Oleh karena itu, komunikasi yang dilakukan karyawan difabel dengan pemilik dan pengelola maupun antar sesama karyawan difabel di UMKM Batik Wistara Indonesia penggunaan bahasa isyarat digunakan setiap hari sebagai media berkomunikasi, selama pesan dapat tersampaikan dengan baik.

\section{c. Saling Menghargai dan Memahami Komunikasi Sebagai Faktor Pendukung}

Komunikasi yang dilakukan baik antara karyawan difabel dengan pemilik, pengelola dan pendamping maupun antar sesama karyawan difabel lainnya memiliki umpan balik yang cukup positif dimana antara orang yang terlibat komunikasi memahami pesan yang disampaikan.

Dari analisis pengamatan peneliti saat berada di Batik Wistara Indonesia. Seluruh orang yang terlibat dalam komunikasi memiliki sikap saling menghargai dan memahami. Dalam hal ini, sikap saling menghargai dan memahami kekurangan dari lawan bicara dapat membantu dalam proses komunikasi. Sikap saling menghargai dan memahami berasal dari diri masing-masing individu dalam menghadapi situasi.

Pak Ari selaku pemilik yang memahami keterbatasan komunikasi yang dimiliki karyawan difabel, lebih menghargai jika kemungkinan pesan tidak langsung bisa dipahami oleh karyawannya. Bu Marni dan Harum adalah orang yang hidup bersama dengan karyawan difabel setiap harinya jadi saat proses komunikasi berlangsung mereka lebih bisa menghargai dan memahami kemampuan yang dimiliki oleh karyawan difabel.

Begitu pula sebaliknya dalam mengirim pesan saat berkomunikasi, mereka tidak memaksakan apa yang ingin disampaikan dan lebih menghargai kemampuan yang dimiliki orangorang pada umumnya, serta memahami jika terdapat kesalahpahaman dalam informasi yang diberikan. Sehingga upaya untuk saling menghargai dan memahami saat komunikasi berlangsung menjadi salah satu faktor pendukung dalam proses komunikasi.

\section{d. Memiliki Cara Sendiri dalam Berkomunikasi Sebagai Faktor Pendukung}


Komunikasi dipandang sebagai cara untuk saling bertukar informasi. Dalam hal ini informasi yang disampaikan saat proses komunikasi antara karyawan difabel dengan pemilik, pengelola dan pendamping maupun antar sesama karyawan difabel lainnya memiliki interpretasi untuk saling memahami informasi yang disampaikan. Karena dari hasil analisis peneliti, mereka memiliki cara sendiri dalam berkomunikasi. Selain dengan penggunaan bahasa isyarat, juga gerak tubuh dan juga gerak bibir.

Penggunaan bahasa isyarat yang menambahan gerak tubuh diikuti dengan gerak bibir secara bersamaan merupakan cara mereka sendiri dalam berkomunikasi yang menjadi salah satu faktor pendukung lancarnya proses komunikasi yang dilakukan.

\section{e. Perbedaan Bahasa Sebagai Faktor Penghambat}

Dalam proses komunikasi, tentunya tidak bisa selalu berjalan dengan lancar. Ada beberapa faktor yang menyebabkan komunikasi tidak bisa berjalan dengan baik. Sehingga penyampaian pesan menjadi terganggu. Salah satu faktor utama proses komunikasi dalam pemberdayaan karyawan difabel di UMKM Batik Wistara Indonesia adalah perbedaan bahasa.
Perbedaan bahasa merupakan faktor penghambat utama dalam melakukan komunikasi. Dari proses komunikasi karyawan difabel dengan antar sesama bukan sebuah penghambat. Tetapi dalam proses komunikasi antara karyawan difabel dengan pemilik, pengelola dan pendamping di Batik Wistara Indonesia berbeda, apalagi saat berkomunikasi untuk memberikan pelatihan keterampilan, sangatlah mempengaruhi.

Bahasa dapat berupa bahasa verbal dan bahasa non verbal. Sebagaimana diketahui perbedaan bahasa terletak dari bagaimana karyawan difabel menggunakan bahasa non verbal sedangkan pemilik, pengelola dan pendamping memiliki bahasa verbal dalam kesehariannya.

Pada dasarnya, proses komunikasi dalam melakukan pemberdayaan di UMKM Batik Wistara Indonesia, tidak banyak menimbulkan hambatan, tetapi tetap saja perbedaan bahasa merupakan salah satu faktor penghambat utama dalam proses komunikasi yang dilakukan.

\section{Kesimpulan \\ Berdasarkan pengumpulan data, observasi hingga analisis yang peneliti lakukan maka dapat peneliti simpulkan bahwa Proses komunikasi yang dilakukan karyawan difabel menggunakan model Schramm dan model komunikasi Interaksional, dengan menerapkan pola}


komuniksi lingkaran. Bentuk dari proses komunikasi yang dilakukan adalah komunikasi interpersonal dengan merujuk pada tidak ada batasan dalam berkomunikasi. Pemilik dan pengelola di UMKM Batik Wistara Indonesia, ketika berkomunikasi dengan karyawan difabel di UMKM Batik Wistara Indonesia ini walaupun harus berusaha lebih keras daripada dengan yang lain.

Baik dalam memahami apa yang disampaikan hingga sedikit banyak harus memiliki pengetahuan tentang bahasaisyarat yang digunakan. Oleh karena itu dapat peneliti uraikan secara urut yakni: karyawan difabel mengirim pesan (berupa simbol baik dengan bahasa isyarat, gerak bibir maupun gerak tubuh), selanjutnya pemilik dan pengelola menerima pesan sebisa mereka pahami, pemilik dan pengelola mengirim pesan kembali (berupa simbol baik dengan bahasa isyarat, gerak bibir maupun gerak tubuh), karyawan difabel menerimanya kembali dan memahami sebisanya, kemudian mengirim pesan lagi. Dan begitu seterusnya hingga kedua belah pihak akhirnya sepakat dan pesanan yang diterima sesuai.

\section{Daftar Pustaka}

Andi Maulana Armas, Andi Alimuddin Unde, dan Jeanny Maria Fatimah, Konsep Diri Dan Kompetensi Komunikasi Penyandang Disabilitas Dalam Menumbuhkan Kepercayaan Diri Dan Aktualisasi Diri Di Dunia Kewirausahaan Kota Makassar, Jurnal Komunikasi KAREBA 6 no. 2 (Desember 2017): 277-284. https:// doi.org/10.31947/kjik.v6i2.5328
Antaranews.com., Penyandang disabilitas Spanyol protes penghematan anggaran, September, 25, 2019, http:// www.antaranews.com/print/346542/p enyandang-disabilitas-spanyolprotespenghematan-anggaran

BPKP - Unduhan UU RI No.4 Tahun 1997, September, 26, 2019, www.bpkp.go.id > uu >

Cangara, Hafied. Pengantar Ilmu Komunikasi, Ed. 2, cet. 13. Jakarta: Rajawali Pers, 2012.

Hoveland, Carl I. Social Communication, Am Phil. Soc, XCII, Dance No. 33/Catg. Stappers 1948.

International Labour Organization Jakarta. Inklusi penyandang disabilitas di Indonesia. Maret 7, 2016, http://www.ilo.org/jakarta/whatwedo/ publications /WCMS_233426 /lang-en/index.htm

Kuncoro, Mudrajat. Masalah, Kebijakan, dan Politik Ekonomika Pembangunan. Jakarta, 2010.

Matthew, A. Michael Hubberman and Miles B. Analisis Data Kualitatif, Terj. Tjejep. Jakarta: UI Press, 1992.

Moloeng, Lexy J. Metode penelitian kualitatif. Bandung: Remaja Rosdakarya, 2006 .

Mulyana, Deddy. Ilmu Komunikasi: Suatu Pengantar, cet. 9. Bandung: PT Remaja Rosdakarya, 2007.

Ngalimun, Ilmu Komunikasi Sebuah Pengantar Praktis. Yogyakarta: Pustaka Baru Press, 2017. 
Nugroho, Sapto dan Risnawati Utami. Meretas Siklus Kecacatan-Realitas Yang Terabaikan. Surakarta: Yayasan Talenta, 2008.

Sarwono, Sarlito W. Psikologi Lintas Budaya, Ed. 1 cet. 1. Jakarta: Rajawali Pers, 2014.

Soemantri, T. Sutjihati. Psikologi Anak Luar Biasa. Bandung : Refika Aditama, 2006.

Suharto, Edi. Membangun Masyarakat Memberdayakan Rakyat Kajian Strategis Pembangunan Kesejahteraan Sosial dan Pekerjaan Sosial. Bandung: PT Revika Aditama, 2010.

Suharto, Edi. Pembangunan, Kebijakan Sosial dan Pekerjaan Sosial: Spektrum pemikiran. Bandung: Lembaga Studi Pembangunan STKS (LSP-STKS), 1997.

Tempo.co, "Penggunaan Bahasa Isyarat di Acara Televisi Akan Diwajibkan" September 2019, $\mathrm{http} / / w w w . t e m p o . c o$.

Uchjana, Effendy Onong. Ilmu Komunikasi Teori dan Praktek. Bandung: PT Remaja Rosdakarya, 2009.

Wiryanto, Pengantar Ilmu Komunikasi. Jakarta: PT Grasindo, 2004. 